\title{
METODE PENGAMBILAN DATA PADA PENGKAJIAN PROSES ASUHAN KEPERAWATAN JULIA RAHMA/ 191101040
}

\section{emasurya123emasurya123@gmail.com}

Latar Belakang Asuhan keperawatan adalah suatu pendekatan untuk pemecahan masalah yang memampukan perawat untuk mengatur dan memberikan asuhan keperawatan. Salah satu manfaat dari penerapan asuhan keperawatan yang baik adalah meningkatkan mutu dan kualitas pelayanan dalam bidang keperawatan (Kozier, 2010). Pengumpulan data merupakan aktivitas perawat dalam mengumpulkan informasi yang sistemik tentang klien. Pengkajian dalam keperawatan adalah tahap awal dari proses keperawatan yang bertujuan untuk mengumpulkan informasi mengenai data pasien. Pengkajian ini harus dilakukan dengan lengkap, akurat dan tepat sesuai dengan kenyataan. Dalam proses pengkajian keperawatan salah satunya ada pengumpulan data pengumpulan data ini bisa dilakukan dengan menggunakan beberapa metode pengumpulan data. Tujuan untuk mengetahui mengenai metode pengambilan data pada pengkajian proses asuhan keperawatan di rumah sakit. Metode Jurnal ini menggunakan metode perbandingan, penelaahan, atau analisis 10 jurnal dari berbagai sumber seperti referensi jurnal, text book, dan e-book. Penulisan jurnal ini menggunakan metode-metode perbandingan yang isi dan konsepnya berisikan dengan metode pengambilan data pada pengkajian proses asuhan keperawatan. Hasil yang didapat menyatakan bahwa metode pengambilan data pada pengkajian proses asuhan keperawatan yang diberikan pada klien membutuhkan catatan dan pelaporan yang dapat digunakan sebagai tanggung jawab dan tanggung gugat dari berbagai kemungkinan masalah yang dialami klien baik masalah kepuasan maupun ketidakpuasan terhadap pelayanan yang diberikan. Kesimpulan pengambilan data merupakan bukti pencatatan dan pelaporan yang dimiliki perawat dalam melakukan catatan perawatan yang berguna untuk kepentingan klien, perawat, dan tim kesehatan dalam memberikan pelayanan kesehatan.

Kata Kunci : Metode pengambilan data, Pengkajian Keperawatan, Asuhan keperawatan 


\section{LATAR BELAKANG}

Asuhan keperawatan adalah suatu pendekatan untuk pemecahan masalah yang memampukan perawat untuk mengatur dan memberikan asuhan keperawatan. Salah satu manfaat dari penerapan asuhan keperawatan yang baik adalah meningkatkan mutu dan kualitas pelayanan dalam bidang keperawatan (Kozier, 2010).

Dalam buku Konsep Dasar Keperawatan (asmadi, 2008) Pengumpulan data merupakan aktivitas perawat dalam mengumpulkan informasi yang sistemik tentang klien. Dalam buku Proses keperawatan dan berpikir kritis (Deswani, 2009) pengumpulan data adalah suatu proses pengkajian dengan mengumpulkan informasi tentang status kesehatan klien secara sistematis dan terus menerus.

Pengkajian dalam proses keperawatan merupakan tahap awal dari semua proses keperawatan yang bertujuan untuk mengumpulkan informasi data pasien di rumah sakit, mungukur data, memvalidasi data, dan yang terakhir mendokumentasikan data yang diperoleh. Pengkajian juga bisa disebut dengan pengumpulan, pengaturan, validasi, dan mendokumentasikan data secara sistematis dan berkesinambungan. Contohnya, pada fase evaluasi, pengkajian dilakukan untuk menentukan hasil strategi keperawatan dan mengevaluasi pencapaian tujuan. Semua proses keperawatan sangat bergantung pada pengumpulan datanya apakah akurat atau tidak lengkap. (Kozier, 2010)

\section{TUJUAN}

1. Tujuan umum untuk mengetahui mengenai metode pengambilan data pada pengkajian proses asuhan keperawatan di rumah sakit.

2. Tujuan khusu

- untuk mengetahui metode dalam pengambilan data

- untuk mengetahui proses dalam pengkajian data

- untuk mengetahui langkah-langkah dalam pembuatan data keperawatan.

\section{METODE}

Jurnal ini menggunakan metode perbandingan, penelaahan, atau analisis 10 jurnal dari berbagai sumber seperti referensi jurnal, text book, dan e-book. Penulisan jurnal ini 
menggunakan metode-metode perbandingan yang isi dan konsepnya berisikan dengan metode pengambilan data pada pengkajian proses asuhan keperawatan.

\section{HASIL}

Berdasarkan hasil pencarian literature review dengan menganalis jurnal, ebook, dan text book didapatkan bahwa pada proses pengkajian keperawatan pada tahap pengumpulan data dapat menggunakan metode pengumpulan data, agar pada saat meberikan asuhan keperawatan kepada pasien perawat tidak sulit mengumpulkan data dari pasien. setelah menganalis jurnal dan text book juga didapatkan bahwa perawat di rumah sakit lebih mudah pada saat mengumpulkan data dengan menggunakan metode pengumpulan data.

Metode pengumpulan data yang digunakan di rumah sakit yaitu: observasi, wawancara, dan pemeriksaan. Perawat juga ada yang menggunakan ketiganya secara sekaligus agar pengumpulan data lebih mudah dan hasilnya lebih akurat dan sistematis. Data yang diperoleh pada saat melakukan pengumpulan data dengan menggunakan metode adalah data subjektif dan data objektif. Data subjektif adalah data yang diperoleh dari pasien yaitu suatu pendapat pasien bagaimana kesehatannya saat ini, data ini tidak bisa ditentukan oleh perawat atau berdasarkan kesimpulan yang dilihat dari fisik pasien saja tidak bertanya langsung. Kemudian ada yang namanya data objektif, data ini merupakan data yang diperoleh dangan cara mengobservas.

\section{PEMBAHASAN}

Metode pengumpulan data yang digunakan perawat di rumah sakit menurut analisis jurnal ada tiga macam yang pertama adalah observasi, wawancara, dan pemeriksaan. Penjelasan ketiganya adalah sebagai berikut:

\section{Observasi}

Mengobservasi data merupakan suatu metode pengumpulan data dengan menggunaka indra. Observasi ini dilakukan dengan sengaja dan sadar dengan upaya pendekatan. Selama metode observasi berlangsung perawat melibatkan semua panca indra baik itu melihat dan mendengar apa yang dikatakan pasien. pada saat perawat menggunakan indra penglihatan contohnya itu, ukuran tubuh, berat badan, postur dan kerapian pasien. gestus wajar dan ekspresi pasien apakah pasien tidak nyaman. Dan kedua pada saat menggunakan panca indra penciuman contohnya itu, bau tubuh atau bau 
napas. Dan indra pendengar contohnya, bunyi jantung, suara paru, bising usuu, kemampuan untuk berkomunikasi, bahasa yang dipakai dan kemamnpuan untuk memulai percakapan. Teralhir adalah indra peraba contohnya, suhu dan kelembapan kulit. (Deswani, 2009) Pada saat mengobservasi terdapat dua tahap yaitu: memerhatikan data, dan menyeleksi, mengatur, dan mengiterpretasikan data. Perawat pada saat mengobservasi juga harus mempunyai pengetahuan yang matang karena apabila perawat salah dalam melakukan observasi pasien bisa saja marah dan tidak mau dirawat lagi. Observasi harus dilakukan dengan sedemikian rupa tidak boleh ada yang terlewatkan, karena kebanyakan perawat tidak mengikuti aturan pada saat mengobservasi pasien. observasi juga harus berurutan antara lain sebagai berikut:

- Tanda klinis adanya masalah pada pasien

- Ancaman terhadap keamanan pasien, actual atau potensial

- Adanyan dan berfungsinya peralatan yang terkait

- $\quad$ Lingkungan sekitar termasuk orang-orang didalamnya. (Kozier, 2010)

\section{Metode Wawancara}

Wawancara adalah metode pengumpulan data yang direncanai dan disepkati oleh kedua pihak pasien dan perawat. Tujuan dari metode wawancara ini adalah untuk mengetahui informasi mengenai kesehatan pasien, mengidentifikasi masalah pasien, dan mengevaluasinya. Salah satu contoh wawancara yaitu riwayat kesehatan keperawatan pasien. pada saat melakukan wawancara ada dua pendekatan wawancara yaitu: wawancara direktif dan wawancara nondirektif. Wawancara direktif merupakan wawancara yang sangat terstruktur dan menghasilkan informasi khusus. Sedangkan wawancara nondirektif atau sering disebut dengan wawancara membina hubungan. Pada wawancara ini perawat memberikan kesempatan kepada pasien untuk menceritai yang dialami oleh pasien dan perawat menanggapinya. Pada saat melakukan wawancara ada yang namanya pertanyaan dari perawat ke pasien. ada empat jenis pertanyaan pada saat melakukan wawancara diantaranya yaitu:

- Pertanyaan tertutup, pertanyaan ini digunakan dalam wawancara direktif, bersifat restriktif dan biasanya hanya memerlukan jawaban "ya" atau "tidak" atau jawaban factual singkat yang memberikan informasi yang spesifik dari pasien. pertanyan tertutup ini sering dimulai dengan pertanyaan $5 \mathrm{~W} 1 \mathrm{H}$.

- Pertanyan terbuka, pertanyaan ini sesuai dengn wawancara nondirektif mengajak pasien untuk menjelaskan mengenai kesehatan pasien. pertanyaan 
terbuka hanya menybutkan topik luas untuk didiskusikan, dan mendorong pasien untuk menjawab sedetailnya. Pertanyaan terbuka ini dimulai dengan "apa" atau "bagaimana".

- Pertanyann netral. Pertanyaan ini adalah pertanyaan yang dapat dijawab oleh pasien tanpa arahan dari perawat terlebih dahulu dan digunakan dalam wawancara nondirektif.

- Pertanyaan terarah, pertanyaan ini adalah kebalikan dari pertanyaan netral yang perlu pasien perlu diarahkan dulu oleh perawat, pertanyaan ini digunakan pada wawancara direktif. (Kozier, 2010)

Pada saat melakukan wawancara perawat juga harus merencanakan wawancara tersebut dan tempatnya dimana, waktu, dam susunan tempat duduk serta bahasa yang digunakan, perawat alangkah baiknya menggunakan bahasa yang mudah dipahami oleh pasien. Kemudian tahap wawancara juga harus diperhatikan dengan baik, ada tahap pembukaan dan penutup.

\section{Metode Pemeriksaan}

Pemeriksaan yang dimaksud disini adalah metode dengan memeriksa langsung keadaan fisik pasien. metode ini juga menggunakan observasi dengan panca indra untuk mengetahui masalah kesehatan pasien. Pemeriksaannya dengan sistematis dengan pendekatan sistem tubuh dengan pasien. pada saat melakukan pengumpulan data dengan menggunakan metode ini perawat harus langsung mencatat hasil dari pemeriksaan

Dalam buku Konsep Dasar Keperawatan (Budiono \& Sumirah, 2016) Teknik pengumpulan data yang dapat dilakukan adalah dengan melakukan pengkajian untuk memperoleh data sesuai dengan keperluan dan masalah yang dihadapi oleh klien seperti berikut :

\section{a. Anamnesis}

Anamnesis adalah suatu proses tanya jawab atau komunikasi untuk mengajak klien dan keluarga bertukar pikiran dan perasaan, mencakup keterampilan secara verbal dan non verbal, empati dan rasa kepedulian yang tinggi. Teknik verbal meliputi : pertanyaan terbuka atau tertutup, mengali jawaban dan memvalidasi respons klien. Sementara itu, teknik non verbal, meliputi : mendengar secara aktif, diam, sentuhan dan kontak mata. Unsur yang harus dicermati dalam mendengar secara aktif, meliputi:

- Memperhatikan pesan yang disampaikan dan hubungannya dengan pikiran. 
- Mengurangi hambatan hambatan

- Posisi duduk yang sesuai

- Menghindari interupsi

- Mendengarkan secara seksama setiap perkataan klien

- Memberikan kesempatan istirahat kepada klien

Tujuan komunikasi yang dilakukan dalam pengkajian data keperawatan

- Mendapatka informasi yang diperlukan dalam mengidentifikasi dan merencanakan tindakan keperawatan.

- Meningkatkan hubungan anda dengan klien dalam komunikasi

- Membantu klien memperoleh informasi dan berpartisifasi dalam identifikasi masalah dan tujuan

- Membantu anda untuk menentukan investigasi lebih lanjut selama tahap pengkajian. (Iyer et.al., 1995)

b. Observasi

Observasi adalah pengamatan perilaku dan keadaan klien untuk memperoleh data tentang masalah kesehatan dan keperawatan klien. Kegiatan obsevasi, meliputi 2S HFT : Signt, seperti kelainan fisik, perdarahan, terbakar, dan menangis. Smell, seperti alkohol, darah, feses, obatobatan dan urine. Hearing, seperti tekanan darah, batuk, menangis ekspresi nyeri, heart rate, dan ritme. Feeling, seperti daya rasa. Taste, seperti cita rasa.

c. Pemeriksaan fisik

Pemeriksaan fisik yang dilakukan dengan menggunakan metode atau teknik P.E. (Physical Examination) yang terdiri atas :

- Inspeksi yaitu teknik yang dilakukan dengan proses observasi yang dilaksanakan secara sistematik.

- Palpasi yaitu suatu teknik yang dapat dilakukan dengan menggunakan indra peraba.

- Perkusi adalah pemeriksaan yang dapat dilakukan dengan mengetuk, dengan tujuan untuk membandingkan kiri kanan pada setiap daerah permukaan tubuh dengan menghasilkan suara.

- Auskultasi merupakan pemeriksaan yang dapat anda lakukan dengan mendengarkan suara yang dihasilkan oleh tubuh dengan menggunakan stetoskop. 


\section{PENUTUP}

\section{Kesimpulan}

Kesimpulan dari kajian ini adalah proses keperawatan salah satunya adalah pengkajian keperawatan, dalam pengkajian keperawatan ada pengumpulan data pada saat melakukan pengumpulan data perawat akan susah dan sulit melakukannya apabila tidak mengetahui prosedur, cara atau metode dari pengumpulan data tersebut. Dengan mengetahui metode pengumpulan data perawat juga akan lebih mudah dan menghasilkan data yang lebih akurat dan sistematis.

Pengumpulan data merupakan suatu proses pengkajian dengan mengumpulkan informasi tentang status kesehatan klien secara sistematis dan secara terus menerus. Teknik pengumpulan data yang dapat dilakukan adalah dengan melakukan pengkajian untuk memperoleh data sesuai dengan keperluan dan masalah yang dihadapi oleh klien seperti berikut : anamnesis, observasi, dan pemeriksaan fisik. Keseluruhan rencana asuhan keperawatan yang dibuat sepenuhnya akan bergantung pada data yang dikumpulkan. Yakinkan bahwa setiap data yang di peroleh adalah benar, lengkap dan terorganisasi.

\section{Saran}

Mengingat pentingnya pengumpulan data pada pengkajian keperawatan direkomendasikan agar perawat mengetahui metode dari pengumpulan data agar data yang diperoleh lebih akurat dan asuhan keperawatan yang akan diberikan terlaksana.

\section{REFERENSI}

Budiono. (2016). Konsep Dasar Keperawatan. Jakarta: Pubsdik SDM Kesehatan.

Budiono \& Sumirah. (2016). Konsep Dasar Keperawatan. Jakarta: Bumi Medika

Dermawan, D. (2012). Proses Keperawatan Penerapan Konsep \& Karangka Kerja. Yogyakarta: Gosyen

Herdman, T. H. (2018). NANDA-I Diagnosis Keperawatan. Jakarta: EGC

Kozier, Erb, Berman, \& Snyder. (2010). Buku Ajar Fundamental Keperawatan Konsep, Proses, \& Praktik. Jakarta: EGC.

Rachman, N. (2016). Applied Nanda, NIC, NOC, Pada Praktek Klinik Keperawatan Kebutuhan Dasar Manusia. Yogyakarta: Trans Medika 
Rosdahl, C. B., \& Kawalski, M. T. (2017). Buku Ajar Keperawatan Dasar. Jakarta: EGC..

Rosdahl, B.C \& Kowalski, T.M. (2014). Buku Ajar Keperawatan Dasar. Ed.10.Vol 1. Jakarta: EGC.

Rutami. (2012, Oktober). Pelaksanaan Proses Pengkajian Keperawatan di Ruang Rawat Inap RSUP H. Adam Malik Medan. Jurnal Keperawatan, 1(2).

Simamora, R. H. (2019). Menjadi perawat yang: CIH'HUY. Surakarta: Kekata Publisher.

Simamora, R. H. (2005). Hubungan Persepsi Perawat Pelaksana Terhadap Penerapan Fungsi Pengorganisasian Yang Dilakukan Oleh Kepala Ruangan Dengan Kinerjanya Diruang Rawat Inap RSUD Koja Jakarta Utara (Doctoral dissertation, Tesis FIK UI, Tidak dipublikasikan).

Tarwoto, \& Wartono. (2015). Kebutuhan Dasar Manusia dan Proses Keperawatan. Yogyakarta: Salemba Medika

Tuhareal, Novan Aries, dkk. 2017. Sistem Komputerisasi untuk Pencatatan Laporan Asuhan Keperawatan untuk Mahasiswa Ilmu Keperawatan. Citec Journal, 04(04), 245 253 